\title{
Selective Abortion and Folic Acid Fortification as Contrasting Strategies for Prevention of Congenital Neural Tube Defect
}

\author{
John A. A. Nichols \\ The Postgraduate Medical School, \\ The University of Surrey \\ UK
}

\section{Introduction}

Prenatal diagnosis of severe disability and the option of termination of pregnancy (TOP) have been widely available to parents in most countries in the Western world for three decades. This has come to be known as selective abortion. The ethics of this procedure is a large subject that I will not attempt to address in this paper. Some countries have laws that forbid selective abortion unless the mother's life is at risk. Where neural tube defects (NTDs) are concerned, medical opinion might favour TOP in a mother carrying an anencephalic fetus. The anencephalic infant will not normally survive for more an hour after birth but the mother may have a difficult and even life threatening labour because the lack of a fetal head prevents normal labour from progressing. The pregnancy tends to go overdue and vaginal delivery is complicated by shoulder dystocia and can be very difficult and hazardous for the mother. However $60 \%$ of women in the world would not be able to access an early TOP for this type of pregnancy due to poverty, religious reasons or anti-abortion legislation. In the republic of Ireland, which has anti-abortion legislation, this situation has encouraged legislators to consider minimising the need for selective abortion by introducing mandatory fortification of flour with folic acid (FA).

\subsection{Objections to folic acid fortification of bread, flour and grain}

Scientists, oncologists and politicians have urged caution in implementing folic acid fortification of bread, flour and grain. Oncologists were amongst the first to point out that many cancer chemotherapy drugs work by inhibiting folate metabolism and subsequent research showed that giving folic acid can accelerate tumour growth in animal models (Hubner et al., 2007). The arguments for and against fortification depend on the interpretation of data from countries where fortification has already been implemented. In Chile, which has similar anti-abortion legislation to The Republic of Ireland, a ten year policy of fortification has reduced the incidence of NTD births by $40 \%$ - from $17 / 10,000$ births to 10.1/10,000 births (Hertrampf et al., 2004). However the UK and Irish governments have held back on fortification and the following issues have caused pause for thought: 


\subsubsection{There has been a slight increase in colorectal and prostate cancer in middle life in the USA}

Mandatory FA fortification has been in force for ten years in the USA and Canada and the incidence of NTD conceptions has dropped $20-40 \%$ varying between different regions of North America. However, a slight increase in the incidence of colorectal and prostate cancer was noticed which coincided with the introduction of fortification (Mason et al., 2007).The latest paper from the USA on colorectal cancer since fortification $(n=535,000)$ showed that far from an increased risk, subjects with the highest folate intakes were $30 \%$ less likely to develop cancers (Gibson et al., 2011).

\subsubsection{Supplementation trials and cancers risk}

A trial comparing FA supplementation and low dose aspirin with placebo suggests that giving folic acid 1000 microgram daily increases the risk of middle life cancers, especially colorectal and prostate (Cole et al 2007). This is thought to occur in folate replete populations when an unnaturally high folate status accelerates cell proliferation in early cancers. However, supplementation with folic acid and other B vitamins in folate deficient populations and populations where there is a high incidence of the gene for slow folate metabolism (MTHFR C677T) may decrease the risk of these cancers (Le Marchand et al., 2002; Figueiredo et al., 2011).

\subsubsection{Masking of vitamin B12 deficiency}

Masking of B12 deficiency by giving folic acid for macrocytic anaemia was a problem in the last century but B12 deficiency is much less likely to go undiagnosed in a modern medical setting. However, there have been warnings that folic acid fortification might have an adverse effect on B12 status and cognitive function in older age groups (Clarke et al., 2004).

\subsubsection{Folic acid in not a natural substance}

Folates are the natural form of the vitamin and are present in fruit and vegetables whereas FA is a synthetic man made substance. However, folates are labile molecules that break down with storage and heat. Folic acid is a relatively stable synthetic molecule and is quickly metabolised into the folate pathways in small quantities but a high dose may not be metabolised so well. High intake of FA results in a measurable residue of circulating folic acid which could, theoretically, have adverse effects, on the development of the fetal central nervous system for instance (Smith et al., 2008). Research in Ireland has shown that fortification that delivers a dose of 100 microgram daily is safe, in this respect. There was no detectable unmetabolised serum folic acid at this dose (Sweeney et al, 2007).

\subsubsection{0\% of NTD conceptions will still occur}

The precise reason for this is unknown but some genetic combinations may make the development of some NTDs inevitable. However, other B vitamins are involved in the folate-methionine-homocysteine cycle (Figure 1; McNulty et al., 2002). Instability of this cycle and build up of high levels of homocysteine are thought to play a key role in delaying neural tube closure (Rosenquist et al., 2002). Zinc deficiency might also be a factor in some NTDs (Srinivas et al., 2001). 


\subsection{Benefits from public health measures for prevention of NTDs}

In terms of public health benefit, we should also concern ourselves with the efficacy of folic acid fortification compared with the policy in the United Kingdom and other European countries where women are encouraged to take folic acid $400 \mu \mathrm{g}$ daily starting about six weeks before a planned conception and offered ultrasound screening and the option of TOP if a NTD fetus is diagnosed. Is prevention of NTD conceptions by folic acid fortification a valid alternative? It has the advantage that the $40 \%$ of conceptions that are unplanned but not unwanted (Botto et al., 2005; Gipson \& Stanelli, 2011) will benefit from this policy whereas the UK policy will only achieve an intake of folic acid sufficient to reduce the risk of NTD conceptions in $60 \%$ of subjects at the very most. However, the concordance rate for starting folic acid before conception in planned pregnancies is poor and does not seem to make a significant impact on the incidence of NTD conceptions (Botto et al., 2005). The best concordance data shows only $10-20 \%$ of women with both planned pregnancies and starting a folic acid supplement before conception (Rezan et al., 2002).

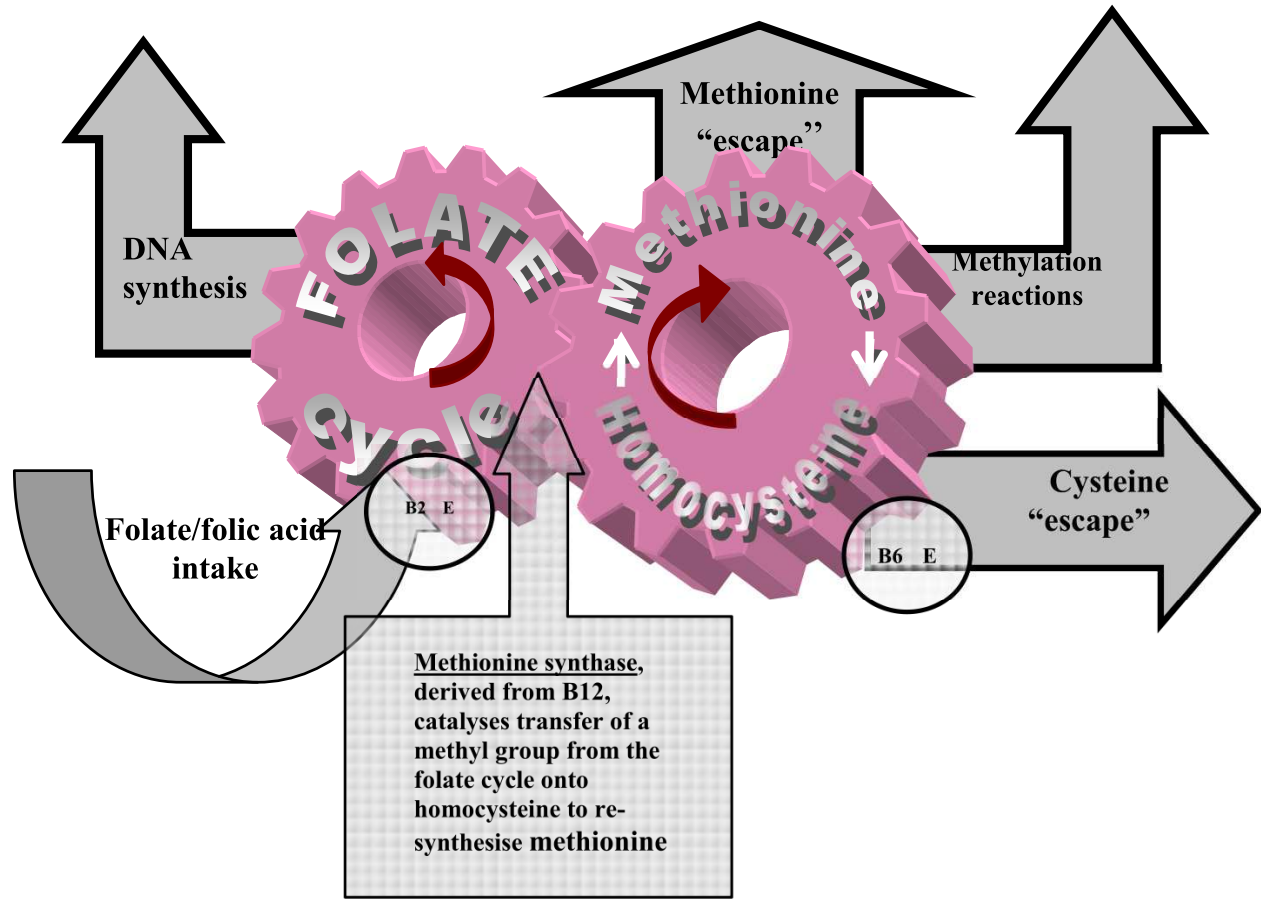

B2 E denotes an enzyme pathway dependant on vitamin B2

B6 E denotes an enzyme pathway dependant on vitamin B6

Fig. 1. Simplified version of the folate-methionine-homocysteine cycle illustrating the role of vitamins B2 (riboflavin), B6 (pyridoxine) and B12 (cobalamin) in modulating the cycle and directly or indirectly lowering homocysteine burden. 


\subsection{Objections to policy of pre-conception advice with option of selective abortion}

Having listed the objections to fortification, we need to consider the reasons why a policy of advising pre-conception folic acid and ultrasound screening for NTDs in early pregnancy may be considered unsatisfactory. This will always involve a significant number of women being offered TOP as an option when screening shows a NTD fetus.

\subsubsection{Pre-conception folic acid concordance has failed}

The level of success for starting folic acid before conception is too low to make a measurable impact on the rate of NTD conceptions. Since the neural tube develops before a woman knows she is pregnant, starting folic acid as soon as pregnancy is confirmed will never make a noticeable impact on the incidence of NTD conceptions. According to a survey based on data for England and Wales published by the UK Office for National Statistics (Morris \& Wald, 2007) 969 NTD conceptions were recorded in 2004 (801 women had TOPs for NTD but 168 were recorded as going to term with NTD infants). The authors estimate that there are 1,100 NTD conceptions in the whole of the UK (if Scotland and Northern Ireland are included).

\subsubsection{Selective abortion is a psychological trauma}

The distress to mothers who opt for selective abortion for a NTD conception is a significant issue. A review of the evidence on the impact of selective abortion concludes that women experience a bereavement reaction that is similar to that experienced with a stillbirth (Statham et al., 2000).

\subsubsection{Screening misses a significant proportion of NTDs}

The data from Morris and Wald indicates that a significant minority of NTDs are missed on ultrasound screening (see 1.2.1) which is approximately $17 \%$ of all NTD conceptions. However, another source of error is the pregnancies that spontaneously abort due to NTDs which has been estimated at 600-1200 per year in the UK (UK Department of Health report 2000). In at least half of these aborted foetuses NTD is caused by chromosomal abnormalities so that folate status has no bearing on aetiology or prevention. However, some women with NTD conceptions who spontaneously abort in this way might have benefitted from increased intake of FA before conception and they certainly get no benefit from the policy of selective abortion.

\subsection{Assessing the case for folic acid fortification in the UK and Ireland}

The success of fortification in Chile and North America is encouraging and the recent data on cancers in these countries has reassured the public health experts that the apparent increased risk of cancers with fortification is either very small or just a statistical aberration. It is particularly significant that the USA and Canada have not wavered from the policy of FA fortification. Ultimately, the question of whether fortification is a cost-effective exercise has to be addressed. This can be estimated by comparing: A/ costs mandatory fortification reimbursed to UK millers by government = government reimbursement to millers for 
adding folic acid $140 \mu \mathrm{g} / 100 \mathrm{mg}+$ cost of government monitoring B/ government savings from mandatory fortification $=$ cost of TOP $x$ drop in number of TOPs done for NTD+ lifetime medical cost of treatment for NTD patients $x$ drop in number of NTD births This can be estimated for the UK from Morris and Wald's data on selective abortion for NTDs and live NTD births who survive infancy and from research carried out in Surrey (Nichols et al 2008a) using data on total folate intake from a women attending local midwives' booking in clinics.

\section{Estimation of benefits of UK adopting policy of mandatory folic acid fortification of flour and bread}

The research carried out by the author and colleagues at The University of Surrey, UK was used, with data from other sources, to estimate the impact of fortification for the whole nation.

\subsection{Two groups of women were investigated}

a. Eighteen Surrey women were assessed for dietary folate intake as part of a larger research project (Nichols et al 2008b) which assessed dietary folate intake using weighed food diet diaries. Each subject was given a seven-day diet diary to complete and given the use of battery operated microtonic scales with detailed instructions. Research has demonstrated the weighed seven-day diet diary to be a reasonably accurate tool for measuring nutrient intake in free-living individuals (Day et al., 2001, Nelson et al 1998). The diet diary data was entered into "WinDiets Professional", a computerised database for analysis of nutritional intake (Wise, 1999). The output included an estimate of daily folate intake for each of the 18 subjects. Although this was a small sample, the mean folate intake at $267 \mu \mathrm{g} /$ day was very similar to the UK national averages from the UK National Diet and Nutritional Survey 2002 (229 $\mu \mathrm{g} /$ day for women aged 19-24 yr, $234 \mu \mathrm{g} /$ day for women aged 25-34 yr). Therefore the figure of $267 \mu \mathrm{g} /$ day was assumed to be the approximate dietary intake for group B women and the basis for calculating total folate intake by adding together this presumed dietary folate and folic acid supplementation in the larger sample of Surrey Group B women attending the district midwife booking-in clinic.

b. 200 women were asked to complete questionnaires when they attended midwives' booking in clinics in the catchment area of The Royal Surrey Count Hospital. The response rate was $43.5 \%$. The women were asked to complete the questionnaire and return it to the researchers in a stamped addressed envelope. The questions asked the following:

- whether the pregnancy was planned or unplanned

- $\quad$ whether the pregnancy was natural or an assisted pregnancy

- whether a supplement was started before or after conception

- $\quad$ if before conception, number of weeks taken

- $\quad$ exactly what brand(s) of supplement was used

- $\quad$ age, and age at completion of education

With a good response rate, this sample was thought to be adequate to calculate statistical significance for the different amounts of folic acid in the different over-the-counter supplements and for estimation of total folate intake (TFI). 


\subsection{Estimation of total folate intake}

Owing to the poor availability of dietary folate resulting from loss of folate content in cooking and poor absorption of food folate compared with synthetic folic acid (McKillop et al., 2002; Standing committee on the Scientific Evaluation of Dietary Reference Intakes, Washington DC, 1998), various authorities have recommended a downward adjustment of approximately $50 \%$ for dietary folate (Eichholzer et al., 2006) when calculating a combined value for dietary folate/day + FA/day (FAD). Therefore, corrected total folate (TFI) was calculated using the estimated mean dietary intake for all Group B Surrey women (DM) using the formula:

$$
\mathrm{TFI}=[(\mathrm{DM}) \div 2]+\text { FADmg } / \text { day }
$$

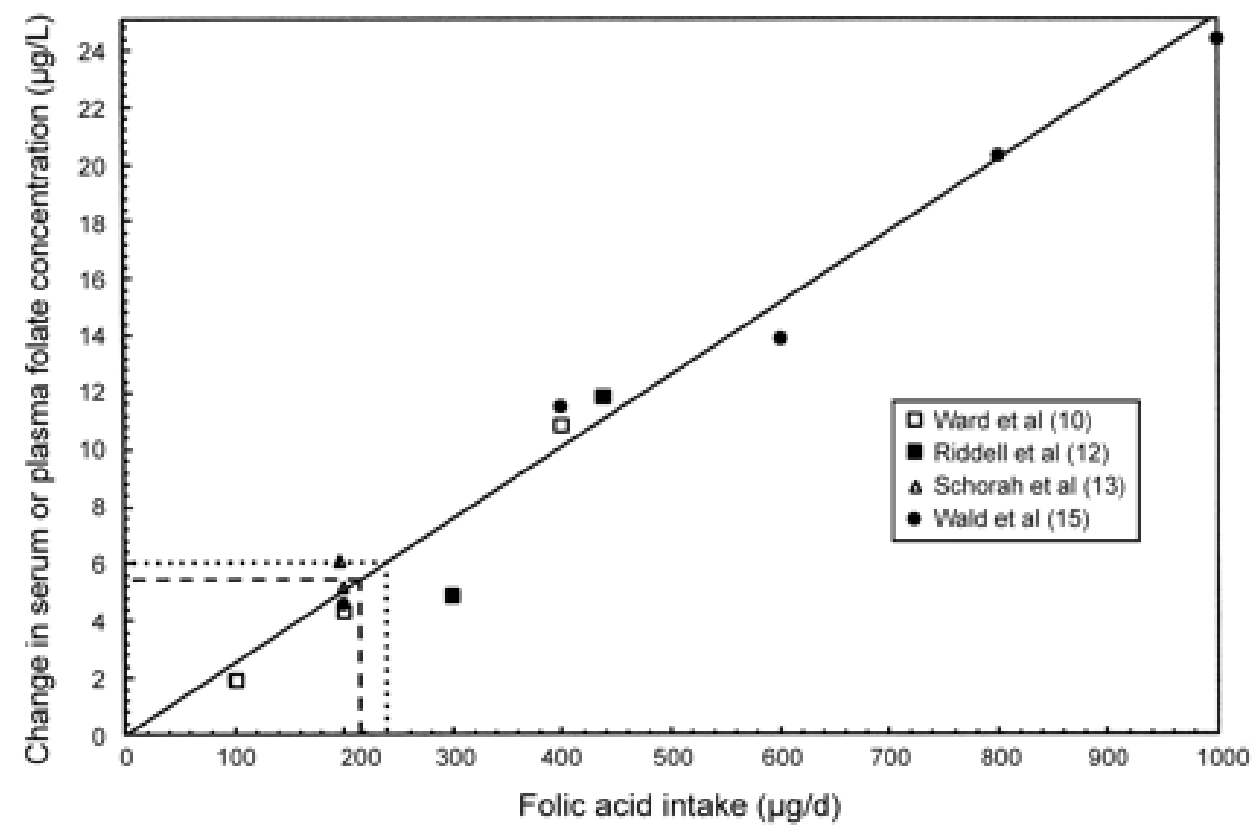

Fig. 2. Relation between controlled folic acid intake and the resulting change in median or adjusted mean serum or plasma folate concentration. Data were derived from intervention studies looking at the effect of longitudinal folic acid supplementation or fortification with known daily amounts of folic acid on median or adjusted mean serum or plasma folate concentrations. The broken and dotted lines represent the change in plasma or serum folate concentration observed by two research groups (Jacques et al., 2000; Lawrence et al, 1999) respectively, in 2 studies examining the effect of the current US folic acid fortification regimen on folate status. $y=0.0254 x+0.0514(\mathrm{r}=0.984, \mathrm{P}<0.0001)$.

Reproduced with permission by the American Journal of Clinical Nutrition. @ , Am J Clin Nutr. and authors Quinlivan EP and Gregory JF. 
The predicted average uplift from FA fortification at the level of $140 \mu \mathrm{g} / 100 \mathrm{gm}$ of flour TFI is $220 \mu \mathrm{g} /$ day (Eichholzer et al., 2006; Quinlivan \& Gregory, 2003). Figure 2 was used to calculate the uplift of folate intake with fortification which was estimated for women in group B using the formula:

$$
\text { Estimated TFI after fortification }=[(\mathrm{DM}) \div 2]+\mathrm{FAD}+220 \mathrm{mg} / \text { day }
$$

Since at least $70 \%$ of mothers will achieve a serum folate level that prevents the NTD malformation on an intake of $>700 \mu \mathrm{g} /$ day (Homocysteine Lowering Trialist's Collaboration, 2005; Rosenquist \& Finnell 2001) (Figure 1), the data for estimated TFI after fortification was analysed using this standard. $24 \%$ (21/87) of women attending the DMCs had unplanned pregnancies and were younger (mean age $29.8 \mathrm{yr}$, compared with average 33 yr). Numerous surveys suggest that the national average for pregnancies that are unplanned, but not necessarily unwanted, is $40 \%$. However, there were probably a higher proportion of women with unplanned pregnancies among the 113 women who had failed to return a completed questionnaire so that the true figure for Surrey women having unplanned pregnancies may be closer to the $40 \%$ national average. Using the above formula, the expected uplift of TFI was estimated for all pregnancies and separately for unplanned pregnancies (Table 1).

\begin{tabular}{|c|c|c|c|c|}
\cline { 2 - 4 } \multicolumn{1}{c|}{} & $\begin{array}{c}\text { Mean TFI before } \\
\text { fortification }\end{array}$ & $\begin{array}{c}\text { Mean TFI after } \\
\text { fortification }\end{array}$ & $\begin{array}{c}\text { Increased to } \\
>700 \mu \mathrm{g} / \text { day } \\
\text { before-after } \\
\text { fortification }\end{array}$ & $\begin{array}{c}\mathrm{P} \\
\text { values } \\
\text { for } \\
\text { uplift }\end{array}$ \\
\hline $\begin{array}{c}\text { All district } \\
\text { midwife clinic }\end{array}$ & $\begin{array}{c}497 \mu \mathrm{g} / \text { day } \\
(95 \% \mathrm{Cl} 358-635)\end{array}$ & $\begin{array}{c}717 \mu \mathrm{g} / \text { day } \\
(95 \% \mathrm{Cl} 579-855)\end{array}$ & $21 \%-55 \% *$ & 0.01 \\
\hline $\begin{array}{c}\text { Unplanned } \\
\text { pregnancies }\end{array}$ & $\begin{array}{c}160 \mu \mathrm{g} / \text { day } \\
(95 \% \mathrm{Cl} 81-240)\end{array}$ & $\begin{array}{c}380 \mu \mathrm{g} / \text { day } \\
(95 \% \mathrm{Cl} 301-460)\end{array}$ & $4.8 \%-4.8 \%$ & $\mathrm{~ns}$ \\
\hline
\end{tabular}

* $34 \%$ improvement in reaching $>700 \mu \mathrm{g} /$ day TFI

Table 1. Estimated total daily folate acid intake - dietary folate + folic acid (TFI) before and after fortification with folic acid $140 \mu \mathrm{g} / 100 \mathrm{~g}$ of flour as implemented in The USA. P values are given for the difference between number of subjects with an adequate intake of total folate $(700 \mu \mathrm{g} /$ day or more) before and after fortification (from Nichols et al., 2008a).

Only one woman with an unplanned pregnancy had been taking FA $400 \mu \mathrm{g} /$ day (in a multivitamin tablet), compared with $75 \%$ of women with planned pregnancies.

\subsection{Estimation of expected number of NTD malformations averted with folic acid fortification for the UK}

The estimated number of UK NTD conceptions/year is 1100 (Morris \& Wald, 2007). If fortification achieves a national 34\% improvement in the number of women attaining the optimal level of daily TFI $>700 \mu \mathrm{g} /$ day for prevention of NTDs (Homocysteine Lowering Trialist's Collaboration), this would result in 374 of these 1100 women/year reaching this standard. In this "high risk" group, achieving optimal TFI should protect $62-94 \%$ (Berry et al, 1999) $=232-352$ NTD malformations/year averted. Thus approximately 292 infants a year 
will be born normal and healthy after fortification that are currently either being diagnosed as NTD and aborted or born with a NTD malformation. An alternative calculation is based on expected rise in serum folate with fortification (Wald et al., 2003). The rise in serum folic acid in group B subjects was estimated from FA intake before and after fortification by reading off expected plasma folate values from Figure 2:

$$
\begin{gathered}
\text { Estimated plasma folic acid before fortification }=12.6 \mathrm{mg} / \mathrm{L} \\
\text { Estimated plasma folic acid after fortification }=18.4 \mathrm{mg} / \mathrm{L} \\
\text { Estimated change in plasma folic acid }=5.4 \mathrm{mg} / \mathrm{L} \\
\text { Percentage change }=(5.8 / 12.6) \times 100 \%=46 \%
\end{gathered}
$$

Doubling serum folate (100\% rise) halves the risk of NTD (Berry et al., 1999), therefore a $46 \%$ increase would reduce the total number of UK NTD conceptions by 253/year (from 1100 to 847). Therefore from the two methods of calculation a mean value of 273 averted NTD conceptions is assumed, though this may be an underestimate as improving folate intake without reaching the $700 \mu \mathrm{g} /$ day will prevent the NTD malformation in some cases.

\subsection{Estimation of expected cost-benefit balance with folic acid fortification of flour in the UK}

Calculations of cost-benefit expected from folic acid fortification will depend on the balance between:

a. The costs of mandatory fortification

= government reimbursement to millers for adding folic acid $140 \mu \mathrm{g} / 100 \mathrm{mg}$

and

b. government savings from mandatory fortification

$=$ cost of TOP $x$ drop in number of TOPs done for NTD + average lifetime cost of treatment for NTD patients $x$ drop in number of NTDs births

\subsubsection{Cost to the UK government of mandatory folic acid fortification}

The national Association of British and Irish Millers estimated in March 2011 that 5600,000 tonnes of wheat are milled to make flour/year in the UK. The cost per ton for fortification in 2011 British Pounds Sterling, estimated from the experience of fortification and monitoring expenses in Chile (Llanos et al., 2007) is $£ 0.13 /$ ton. Therefore the expected cost of fortification for the UK is $£ 728000$ /year

\subsubsection{Cost saving benefits from UK mandatory fortification}

Of the 273 averted NTD conceptions averted, 17\% (46) will, on past evidence, be NTD births which will be associated with a range of lifetime medical costs and $83 \%$ (227) of women will 
opt for selective abortion. Although I could not find a UK estimate for average lifetime costs of infants that survive birth with an NTD malformation, there were a range of costs from other countries ranging from $£ 15,400-326,000$. The median figure was $£ 240,000$ (Ouyang et al., 2007). However, this was an estimation of mean average costs for the USA and USA medical expenses are higher than UK prices (even the same drugs cost roughly twice as much) and average per capita health expenditure is 2.2 times higher (Kaiser Family Foundation 2008). I assume here that the same $x 2.2$ difference will apply to lifetime NTD medical costs. Therefore an estimate of mean average lifetime NTD medical costs in the UK $=£ 240,000 \div 2.2=£ 109,091$. The UK cost of a therapeutic TOP is $£ 800$. Therefore the annual saving from fortification in British pounds is:

$$
109,091 \times 46+800 \times 227=5,018,181+181,600=5,199,781
$$

\subsubsection{Estimated cost benefit of UK mandatory fortification}

Therefore the estimated annual cost saving of fortification in British pounds is:

$$
4,471,781-728,000=5,126,981
$$

This converts to approximately $\$ 7$ million. A comparison with the estimated savings for Chile in 2001-2001 of only \$2.3 million (Llanos et al., 2007) may be largely because their health services are less able to cope with complex medical problems that arise in children who survive with NTD malformations, early deaths will often occur and this will be associated with lower lifetime costs. The Centre for Disease Control and Prevention, USA gives a much higher estimate of $\$ 453$ million/year. Apart from the higher US costs and larger population, this estimate includes the loss of earning for parents who stop work to care for a spina bifida child which is not included in my estimate for the UK.

\section{Conclusions}

The above figures are only an estimate of the cost-benefit of fortification and there are a number of factors that would have to be taken into consideration if fortification was implemented in the UK. It will never completely eliminate the need for selective abortion or the advisability of women who plan their pregnancies to start taking a FA supplement before conception. We estimated (Nichols et al., 2008a) that $45 \%$ of women in group B would still fail to achieve optimal total folate intake after fortification. When women attend to see a primary care doctor or nurse for contraceptive advice or review of ongoing contraception, there is an opportunity to raise the importance of pre-conception issues and boost FA concordance whenever there is a possibility of a future planned pregnancy. A comprehensive package of pre-conception care will be even more effective at reducing the risk of NTDs and other congenital malformations as described in section 3.3. The combined effect of fortification and adequate preconception advice, linked to contraceptive advice, could double the number of NTDs averted. This chapter has concentrated on the benefits of FA fortification with respect to averted NTD malformations, but there are other expected benefits and several remaining concerns (Table 2). In particular, there is growing evidence that other fetal malformations are prevented by fortification and FA supplementation has been shown to reduce the risk of intrauterine growth retardation. It is interesting to note 
that most of these benefits from improving folate status were predicted by Bryan Hibbard nearly 50 years ago (Hibbard, 1964) and now we have evidence that improving folate status may also prevent childhood cancers (Table 2). Added to this, there is growing evidence that FA fortification may deliver more benefits than side effects amongst elders (Table 2). It is too soon to claim this as a dependable measure of cost benefit from FA fortification but close monitoring of FA intake, blood folate levels and outcomes may help to clarify matters.

\subsection{Remaining concerns}

After fortification a monitoring protocol should include B12 status in view of the $25-43 \%$ incidence of borderline and moderate vitamin B12 deficiency found in three UK elder studies and the suspicion that high folate intake may exacerbate both B12 deficiency and associated cognitive decline (Green \& Miller, 2005; Table 2) and the evidence for a role for borderline vitamin B12 deficiency in NTD (Ray JG et al., 2007; Molloy et al., 2009;), other fetal malformations and low birth weight (Table 2). The structure of the UK National Health Service (NHS) should make monitoring of B12 status an eminently achievable objective. Another concern is that high folate intake may reduce the efficacy of anti-folate drugs used in treatment of cancers, rheumatoid arthritis and psoriasis (Smith et al., 2008). This, however, is avoidable if these patients are advised to avoid the fortified bread and their folate status is monitored by blood tests, when appropriate. The issue of unmetabolised FA is unresolved but the North American experience of fortification has been encouraging. The predicted problems relating to unmetabolised FA have failed to materialise in the postfortification decade. One prediction is that high levels of unmetabolised FA may have an adverse effect on immune function in elders by inhibiting the action of NK cells. This has only been described in one study (Pfeiffer at al., 2004) and there are no reports to suggest that fortification has caused NK cell problems. Lastly, the possibility that high intake of FA may influence gene expression by modifying epigenetic imprinting (Smith et al., 2008) and this has been demonstrated in animal models but there is, as yet, no evidence that this is harmful to humans. Remaining concerns that have to be taken into consideration and answered are summarized in table 2 .

\begin{tabular}{|c|c|c|}
\hline & Remaining concerns & Answers to concerns \\
\hline \begin{tabular}{|l} 
FA \\
fortification \\
and infant \\
health
\end{tabular} & $\begin{array}{l}15 \% \text { of group B had predicted TFA } \\
\text { above } 1000 \mu \mathrm{g} \text { / day which might } \\
\text { increase unmetabolised FA in } \\
\text { circulation and there are purely } \\
\text { hypothetical suggestions that this } \\
\text { could have adverse affects on fetal } \\
\text { development. However, the USA } \\
\text { have set this safe upper limit due to } \\
\text { relatively slender evidence that } \\
\text { masking of vitamin B12 deficiency } \\
\text { may start at this level (Standing } \\
\text { Committee on the Scientific } \\
\text { Evaluation 1998) which is unlikely } \\
\text { to apply to pregnant women. }\end{array}$ & $\begin{array}{l}\text { Although the evidence linking TFI } \\
\text { with NTDs is strongest, there is also } \\
\text { evidence that FA prevents several } \\
\text { other major congenital } \\
\text { malformations, including congenital } \\
\text { heart defects, limb defects, and } \\
\text { orofacial clefts (Eichholzer et al., } \\
\text { 2006) and fetal trisomy (Eskes et al., } \\
\text { 2006), and that inadequate maternal } \\
\text { TFI plays a role in intrauterine } \\
\text { growth retardation (Relton et al., } \\
\text { 2005a; Relton et al., 2005b) and } \\
\text { lymphoblastic leukaemia in } \\
\text { childhood (Thompson et al., 2001). }\end{array}$ \\
\hline
\end{tabular}




\begin{tabular}{|c|c|c|}
\hline & Remaining concerns & Answers to concerns \\
\hline $\begin{array}{l}\text { FA } \\
\text { fortification } \\
\text { and cancers }\end{array}$ & $\begin{array}{l}\text { Research already mentioned has } \\
\text { raised the possibility that } \\
\text { fortification may increase the } \\
\text { incidence of colorectal and prostate } \\
\text { cancers. Recent trials failed to } \\
\text { confirm this risk (Figueiredo et al., } \\
\text { 2011,Gibson et al., 2011). The initial } \\
\text { increase in these cancers observed } \\
\text { in USA was either very small or a } \\
\text { statistical aberration }\end{array}$ & $\begin{array}{l}\text { FA fortification may have been } \\
\text { responsible for a drop in the } \\
\text { incidence of childhood cancers: } \\
\text { neuroblastomas (French et al., 2003) } \\
\text { and several other childhood cancers } \\
\text { (Preston-Martin et al., 1998; Grupp } \\
\text { SG et al., 2010) and even coloectal } \\
\text { cancers may be averted in subjects } \\
\text { with low folate status (Figueiredo et } \\
\text { al., 2011). }\end{array}$ \\
\hline $\begin{array}{l}\text { Affects of } \\
\text { fortification on } \\
\text { elders }\end{array}$ & $\begin{array}{l}\text { Although low folate status is } \\
\text { known to be a factor in cognitive } \\
\text { decline, FA intake greater than } \\
1000 \mu \mathrm{g} \text { / day may exacerbate } \\
\text { borderline vitamin B12 deficiency } \\
\text { and exacerbate cognitive decline } \\
\text { (Morris et al., 2004; Clarke et al., } \\
\text { 2004; McCracken et al., 2006; } \\
\text { Clarke et al., 2007). }\end{array}$ & $\begin{array}{l}\text { Since fortification was introduced in } \\
\text { North America a } 5 \% \text { reduction in } \\
\text { stroke related mortality has been } \\
\text { observed (Yang et al., 2006; Selhub et } \\
\text { al., 2000). A well established } \\
\text { association between folate status and } \\
\text { cognitive decline was tested in The } \\
\text { Netherlands using } 800 \mu \mathrm{g} / \text { day, given } \\
\text { to subjects with raised serum } \\
\text { homocysteine. This showed a } \\
\text { significantl slowing of the rate of } \\
\text { cognitive decline (Durga et al 2007). }\end{array}$ \\
\hline $\begin{array}{l}\text { General inad- } \\
\text { equacies of FA } \\
\text { fortification }\end{array}$ & $\begin{array}{l}\text { FA fortification does nothing for } \\
\text { borderline deficiencies in the other } \\
\text { B vitamins that are relevant to fetal } \\
\text { development and elder health } \\
\text { issues and the problem of } \\
\text { unmetabolised FA at the suggested } \\
\text { level of fortification has not been } \\
\text { solved. In the Surrey research } \\
\text { (Nichols et al., 2008a) 45\% of } \\
\text { women still had a sub-optimal FA } \\
\text { intake and the USA experience } \\
\text { shows that fortification has failed } \\
\text { to reduce NTD conceptions in some } \\
\text { ethnic groups (Yang et al., 2007). }\end{array}$ & $\begin{array}{l}\text { The established benefits in terms of } \\
\text { averting NTD malformations may } \\
\text { outweigh any remaining concerns. } \\
\text { However, any campaign associated } \\
\text { with introduction of fortification } \\
\text { should emphasize the need for } \\
\text { women to continue to take a pre- } \\
\text { conception B vitamin supplement. } \\
\text { Public policy on voluntary } \\
\text { fortification can be used to control } \\
\text { the excessive levels of FA added to } \\
\text { some products to minimise the risk } \\
\text { of pushing FA intake above } 1000 \\
\mu \mathrm{g} / \text { day. }\end{array}$ \\
\hline
\end{tabular}

Table 2. Remaining concerns about FA fortification compared with established benefits

\subsection{Opportunistic linkage of advice on pre-conception FA to contraception appointments}

First, consider if the patient is likely (or most unlikely) to become pregnant in the future. Second, if future pregnancy is a possibility, ask if they expect to "become pregnant" or "start a family" at some time in the near or distant future. Lastly, offer them the brochure (outlined below) that explains the importance of taking pre-conception FA and, where appropriate, advise them to tell their friends (an intelligent young woman will usually want to do this). 


\section{Before pregnancy}

The government recommends that all women planning to become pregnant should start taking folic acid vitamin tablets from at least six weeks before the planned pregnancy and up to the twelfth week of pregnancy.

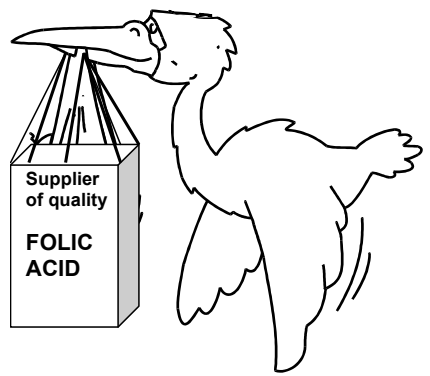

Folic acid plays an important role in the early development of the human embryo. For about 35 years medical scientists have claimed that lack of folic acid is a cause of miscarriage, congenital malformations and handicap but only after particularly convincing research in 1991, has the government recommended a daily tablet of folic acid for all women.Women who have had a previous baby with the rare but serious spinal cord defect "spina bifida" should take a relatively high dose of 5 milligrams, but these women are likely to be under the care of their doctor or a specialist for this treatment. All other women should ask at their chemist for the folic acid $0.4 \mathrm{mg}$ tablet, which should be available at any chemist shop Other pre-pregnancy advice which you may or may not be aware of is listed below.

\section{Non-Smoking}

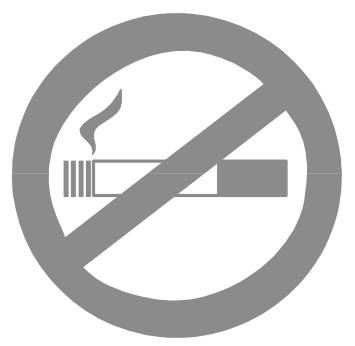

Children of smoking parents are more likely to be born with health problems such as baby asthma. Sometimes smoking may cause serious problems for the baby and when babies are born very underweight this will usually be partly due to smoking before pregnancy, not just during pregnancy. But the effects of smoking are unpredictable and most babies born to smoking mothers will appear to be quite normal. Research has shown, however, that these babies never do quite so well in later life as the children of non-smokers.

\section{Alcohol}

Both parents should cut back on alcohol before conception. Views differ as to what is a safe limit, but it is probably safest for both of you to cut it out completely 


\section{Contraception and smear test}

Women should discuss contraception with the family doctor or practice nurse when they start to plan for pregnancy. Some delay may be advisable if you have had a pregnancy in the last year or two, whatever the outcome. Statistics show that a minimum of 15-month gap between children is advisable. This gives the body time to recover fully. Most experts agree that it is best to switch from the contraceptive pill to another form of contraception two or three months before pregnancy. This allows normal hormone balance to be restored and pregnancy is less likely to be troublesome. There is even some evidence that there is an increased risk of miscarriage when women become pregnant immediately after stopping the pill. Normally, smear tests should be done every three years, but if you are planning to become pregnant, an earlier smear test is advisable - i.e. within the year before attempting to conceive.

\section{Diet}

Although women need extra folic acid as already described, most of the other vitamins, micro nutrients and body building nutrients that are needed for fertility and good health can be obtained from a really healthy diet with plenty of fresh fruit and vegetables and unprocessed whole foods. Recent evidence suggests that eating fish is also beneficial to the outcome of pregnancy, especially in prevention of premature birth. How healthy is your diet? Everyone thinks his or her diet is "quite good" but most of us are in the "could do better" category. Some men and women will benefit from special help with their diet from a doctor or dietician. Pre-conception supplements (e.g. Pregnacare) are available which contain extra micronutrients, in addition to folic acid. This may be helpful if you feel run down and tired or if you have had problems with pregnancy in the past such as a miscarriage or postnatal depression.

Foods which are better avoided before and during pregnancy are:

- $\quad$ Liver and liver products (contain too much vitamin A)

- Swordfish and other large fish should not be eaten around the time of conception or during pregnancy due to traces of mercury

- $\quad$ Soft ripe cheese, pate and raw eggs can contain harmful bacteria that infect the placenta

- Raw meat including cured meat such as parma ham may be a source of toxoplasma parasite (see next section).

- $\quad$ Too much "junk" food such as sweets, biscuits cakes and fizzy drinks

Lastly, remember that you should build up your strength and bodily resources for pregnancy. If you are underweight you may have trouble conceiving and your baby may be underweight at birth, which is not a good start for a baby. Now is not the time to lose weight.

\section{Infection}

Most women will have had a rubella jab at some time, but we now know that it is best to have a blood test to check immunity to rubella, even if you did have the jab at school. Another infection, which very occasionally causes miscarriage or abnormalities, is toxoplasmosis, which is caught mainly from uncooked meat but maybe also from cat faeces. You should, perhaps, avoid contact with sick cats or litter trays whilst you are pregnant. Chickenpox infection during pregnancy also carries a small but significant risk to both mother and baby but if you are sure you have had chickenpox there is nothing to worry 
about. Women who think they have never had chickenpox should discuss this with their doctor. Sexually transmitted diseases are a particular problem when you are planning to start a family. Both the man and woman should attend The Genitourinary Clinic if there is any suspicion of infection as lingering infection can cause infertility or miscarriage and can sometimes have a damaging effect on the baby.

\section{Medical problems}

If you or your partner has a medical problem such as diabetes or epilepsy you should see your doctor for advice before starting a pregnancy. If either of you are on any regular medication for any condition (including over the counter medications) you should discuss this with a doctor or nurse. If you have a family history of a hereditary disease such as Haemophilia or Muscular Dystrophy you should see your doctor about being referred to see a genetic counsellor at a hospital clinic.

\subsection{Implications for future research}

Future considerations include the further development of gene testing to determine which subjects need a higher dose of FA before a first conception rather than waiting for a NTD conception before offering such advice and further consideration of advice on preconception supplementation with the other B vitamins and nutrients such as zinc.

Future research therefore should include:

- Establishing a way of linking contraceptive advice to pre-conception advice on FA supplementation, diet and other aspects of preparation for a healthy pregnancy.

- Resolving the issue of a safe upper limit for total combined folate and folic acid intake, currently set at $1000 \mu \mathrm{g} /$ day.

- Investigating the biochemistry of unmetabolised FA.

- Investigating interactions between folate status and B12 status by monitoring reliable biomarkers for both after fortification and monitoring outcome (NTDs and cognitive decline etc.).

- Further research into gene-nutrient interactions involving B vitamins and both well established genetic variants and candidate genes revealed by genome wide association studies.

A true and accurate cost-benefit analysis for FA fortification can only be completed when this research has been done.

\section{Acknowledgements}

I am indebted to my co-authors and research collaborators, Professor Margaret Rayman of The University of Surrey and Mr. Paul Curtis, consultant Gynaecologist at The Royal Surrey County Hospital, for allowing me to use data from our paper (Nichols et al., 2008). I would have been unable to collect this data without the co-operation of senior community midwife Catherine-Anne Wilkins and her district midwife team based on The Royal Surrey County Hospital. I am especially indebted to the 18 diet diary participants our and 87 supplementation respondents. Lastly, I am grateful for the guidance and help of Dr Andrew 
Taylor of The University of Surrey who helped me to plan and complete the diet diary analysis of the 18 diet diary participants.

\section{Glossary of acronyms}

DM Mean daily dietary folate for group A women (used for group B calculations)

FA Folic acid (also has chemical name pteroylmonoglutamate)

FAD Daily FA intake from supplements

$\mathrm{n} \quad$ Number of participants in a research project

NTD Neural tube defect (the developmental fault in the early embryo that causes spina bifida, hydrocephalus and anencephaly)

TFI Total folate intake (a combined value for dietary folates and FA)

TOP Termination of pregnancy

\section{References}

Berry RJ, Li Z, Erickson JD, Li S et al (1999). Prevention of neural-tube defects with folic acid in China. New Eng J Med;341(20):1485-91.

Botto LD, Lisi A, Robert-Gnansia E, Erickson JD, Vollset SE, Mastroiacovo P, Botting B, Cocchi G, de Vigan C, de Walle H (2005). International retrospective cohort study of neural tube defects in relation to folic acid recommendations: are the recommendations working? British Medical J ournal;330:571.

Clarke R, Grimley Evans J (2004). Reply to NJ Wald et al: Folic acid fortification in the prevention of neural tube defects. American Journal of Clinical Nutrition;79:338-9.

Clarke R, Birks J, Nexo E, Ueland PM, Schneede J, Scott J, e Molloy A, Grimley Evans J (2007). Low vitamin B-12 status and risk of cognitive decline in older adults. Am J Clinical Nutrition;86:1384 - 1391.

Cole BH, Baron JA. Sandler RS, Haile RW, Ahnen DJ, Bresalier RS, McKeown-Eyssen G, Summers RW, Rothstein RI, Burke CA, Snover DC, Church TR, Allen JI, Robertson DJ, Beck GJ, Bond JH, Byers T, Mandel JS, Mott LA, Pearson LH, Barry EL, Rees JR, Marcon N, Saibil F, Ueland PM, Greenberg ER, Polyp Prevention Study Group (2007). Folic Acid for the Prevention of Colorectal Adenomas- A Randomized Clinical Trial. JAMA;297(21):2353-2359.

Day NE, McKeown N, Wong MY. Welch A, Bingham S (2001). Epidemiological assessment of diet: A comparison of a 7-day diary with a food frequency questionnaire using urinary markers of nitrogen, potassium and sodium. International Journal of Epidemiology;30(2):309-317.

Durga J. van Boxtel MP. Schouten EG. Kok FJ. Jolles J. Katan MB. Verhoef P (2007). Effect of 3 -year folic acid supplementation on cognitive function in older adults in the FACIT trial: a randomised, double blind, controlled trial. Lancet;369(9557):208-16.

Eichholzer M, Tönz O, Zimmerman R (2006). Folic acid: a public health issue. Lancet;367:1352-1361. 
Eskes TK, Eur J (2006). Abnormal folate metabolism in mothers with Down syndrome offspring: review of the literature. Obstet Gynecol Reprod Biol;124(2): 130-3.

Figueiredo JC, Mott LA, Giovannucci E, Wu K, Cole B, Grainge MJ, Logan RF,. Baron JA (2011). Folic acid and prevention of colorectal adenomas: a combined analysis of randomized clinical trials. International Journal of Cancer: 129, 192-203.

French AE, Grant R, Weitzman S, Ray JG. Vermeulen MJ. Sung L. Greenberg M. Koren G. (2003). Folic acid food fortification is associated with a decline in neuroblastoma. Clinical Pharmacology and Therapetics;74:288-94.

Gibson TM, Weinstein RM, Pfeiffer RM, Hollenbeck AR, Subar AF, Schatzkin A, Mayne ST, Stolzenburg-Soloman R (2011). Pre- and postfortification intake of folate and risk of colorectal cancer in a large prospective cohort study in the United States. American J of Clinical Nutrition;94(4):1053-1062.

Gipson JD, Stanelli JS (2011). Unplanned and assisted conceptions - high prevelance of unplanned pregnanacy warrants primary and secondary preventon efforts. BM);343:378-9

Green R. Miller JW (2005). Vitamin B12 deficiency is the dominant nutritional cause of hyperhomocysteinemia in a folic acid-fortified population. Clinical Chemistry $\mathcal{E}$ Laboratory Medicine;43(10):1048-51.

Grupp SG. Greenberg ML. Ray JG. Busto U. Lanctot KL. Nulman I. Koren G (2011). Pediatric cancer rates after universal folic acid flour fortification in Ontario. Journal of Clinical Pharmacology;51(1):60-5.

Hertrampf E, Corte's F (2004). Folic Acid Fortification of Wheat Flour: Chile. Nutrition Reviews;62(6):S44-S48.

Hibbard BM (1964). The role of folic acid in pregnancy - with particular reference to anaemia, abruption and abortion. British Jounal of Obstetrics and Gynaecology;71(4):529-542

Homocysteine Lowering Trialist's Collaboration (2005). Dose-dependent effects of folic acid on blood concentrations of homocysteine: a meta-analysis of the randomised trials. Am J Clin Nutr; 82(4):806-12.

Houlston RD, Hubner RA, Muir KR (2007). Should folic acid fortification be mandatory? No. British medical Journal;334:1253

Jacques PF, Selhub J, Bostom AG, Wilson PWF, Rosenberg IH (2000). The effect of folic acid fortification on plasma folate and total homocysteine concentrations. N Engl J Med;340:1449-54.

Kaiser Family Foundation (2008). Health Expenditure Per Capita (PPP; International \$), In: US Global Health Policy-and online gateway for the latest data and information on the US role in global health, Available from:

www.globalhealthfacts.org/data/topic/map.aspx?ind=66

Lawrence JM, Petitti DB,Watkins M, Umekubo MA (1999). Trends in serum folate after food fortification. Lancet;354:915-6.

Llanos A, Hertrampf E, Cortes F, Pardo A, Grosse SD, Uauy R (2007). Cost-effectiveness of a folic acid fortification program in Chile. Health Policy;83:295-30

Le Marchand L, Donlon T, Hankin JH, Kolonel LN et al (2002). B-vitamin intake, metabolic genes and colorectal cancer risk (United States). Cancer Causes $\mathcal{E}$ Control;13(3):239-8.

Mason JB, Dickstein A, Jacques PF, Haggarty P, Selhub J, Dallal G, Rosenberg IH (2007). A temporal association between folic acid fortification and an increase in colorectal 
cancer rates may be illuminating important biological principles: a hypothesis. Cancer Epidemiology, Biomarkers \& Prevention;16(7):1325-9.

McCracken C, Hudson P, Ellis R, McCaddon A (2006). Methylmalonic acid and cognitive function in the Medical Research Council Cognitive Function and Ageing Study. Am J Clin Nutr;84:1406-1411.

McKillop DJ, Pentieva K, Daly D, McPartlin JM, Hughes J, Strain JJ, Scott JM, McNulty H (2002). The effect of different cooking methods on folate retention in various foods that are amongst the major contributors to folate intake in the UK diet. British Journal of Nutrition;88(6):681-8.

McNulty H, McKinley C, Wilson B, et al (2002). Impaired functioning of thermolabile methylenetetrahydrofolate reductase is dependent on riboflavin status: implications for riboflavin requirements. American Journal of Clinical Nutrition;76:436-41.

Molloy AM. Kirke PN. Troendle JF. Burke H. Sutton M, Brody LC, Scott JM. Mills JL (2009). Maternal vitamin B12 status and risk of neural tube defects in a population with high neural tube defect prevalence and no folic Acid fortification. Pediatrics;123(3):917-23.

Morris JK, Wald NJ (2007). Prevalence of neural tube defect pregnancies in England and Wales from 1964 to 2004. Journal of Medical Screening;14(2):55-9.

Morris MC, Evans DA, Bienias JL, Tangney CC, Hebert LE, Scherr PA, Schneider JA (2005). Dietary folate and vitamin B12 intake and cognitive decline among communitydwelling older persons. Archives of Neurology;62(4):641-5.

Nelson M, Bingham SA (1998). Assessment of food consumption and nutrient intake; In: Design Concepts in nutritional epidemiology by Margetts, Nelson M; Oxford University Press: 87-104

Nichols JAA, Curtis EPP, Rayman MP (2008). Survey of total folate intake at conception and assessment of impact of fortification. Journal of Nutritional $\mathcal{E}$ Environmental Medicine;17(1):44-55.

Nichols JAA, Curtis EPP, Rayman MP, Taylor A (2008). A survey to estimate total nutrient intake at conception - Dietary and supplementary. Journal of Nutritional $\mathcal{E}$ Environmental Medicine;17(1):12-43.

Pfeiffer CM, Fazili Z, McCoy L, Zhang M, Gunter EW (2004). Determination of folate vitamers in human serum by stable-isotope-dilution tandem mass spectrometry and comparison with radioassay and microbiologic assay. Clin Chem;50:423-32.

Ouyang L, Grosse SD, Armour BS, Waitzman N J (2007). Health Care Expenditures of Children and Adults with Spina Bifida in a Privately Insured U.S. Population. Birth Defects Research (Part A); 79:552-558.

Ray JG. Wyatt PR. Thompson MD. Vermeulen MJ. Meier C. Wong PY. Farrell SA. Cole DE (2007). Vitamin B12 and the risk of neural tube defects in a folic-acid-fortified population. Epidemiology;18(3):362-6.

Rezan A, Kadir, Demetrios L, Economides (2002). Neural tube defects and periconceptional folic acid. Canadiab Medical Association Journal; 167 (3):255.

Relton CL, Pearce MS, Burn J, Parker L (2005) An investigation of folate-related genetic factors in the determination of birthweight. Paediatric and Perinatal Epidemiology;19(5):360-7. 
Relton CL, Pearce MS, Parker L (2005). The influence of erythrocyte folate and serum vitamin B12 status on birth weight. British Journal of Nutrition;93(5):593-9.

Rosenquist TH, Finnell RH (2001). Genes, folate and homocysteine in embryonic development. Proceedings of the Nutrition Society; 60(1):53-61

Srinivas M, Gupta DK, Rathi SS, Gover JK, Vats V, Sharma JD, Mitra DK (2001). Association between lower hair zinc levels and neural tube defects. Indian Journal of Pediatrics;68(6):519-22.

Selhub J, Jacques PF, Bostom AG, Wilson PW, Rosenberg IH (2000). Relationship between plasma homocysteine and vitamin status in the Framingham study population. Impact of folic acid fortification. Public Health Reviews;28(1-4):117-45.

Smith AD, Youn-In K, Refsum H (2008). Is folic acid good for everyone? American Journal of Clinical Nutrition;87:517 - 33.

Standing committee on the Scientific Evaluation of Dietary Reference Intakes and its Panel on Folate, other B vitamins and Choline and Subcommittee on Upper Reference Levels of Nutriennts, Food and Nutrition Board, Institute of Medicine. Folate. In: Dietary reference intakes for thiamine, riboflavin, niacin, vitamin B6, folate, vitamin B12, pantothenic acid, biotin, and Choline. Washington DC: National Academy Press, 1998:196-305

Statham H, Solomou W, Chitty L (2000). Prenatal diagnosis of fetal abnormality: psychological effects on women in low-risk pregnancies. Best Practice E Research in Clinical Obstetrics \& Gynaecology;14(4):731-47.

Standing committee on the Scientific Evaluation of Dietary Reference Intakes and its Panel on Folate, other B vitamins and Choline and Subcommittee on Upper Reference Levels of Nutriennts, Food and Nutrition Board, Institute of Medicine. Folate. In: Dietary reference intakes for thiamine, riboflavin, niacin, vitamin B6, folate, vitamin B12, pantothenic acid, biotin, and Choline. Washington DC: National Academy Press, 1998:196-305

Sweeney MR, McPartlin J, Scott J (2007). Folic acid fortification and public health: Report on threshold doses above which unmetabolised folic acid appear in serum. BMC Public Health;7:41-48.

Thompson JR, FitzGerald P, Willoughby MLN, Armstrong BK (2001). Maternal folate supplementation in pregnancy and protection against lymphoblastic leukaemia in childhood: a case control study. Lancet;358:1935-1940.

UK Department of health. Report on health and social subjects No. 50. Folic Acid and Prevention of Disease. Report of The Committee on medical aspects of Food and Nutrition Policy. ISBN 011.

Yang Q, Botto LD, Erickson JD, Berry RJ, Sambell C, Johansen H, Friedman JM (2006). Improvement in stroke mortality in Canada and the United States, 1990 to 2002. Circulation;113(10):1335-43.

Yang QH, Carter HK, Mulinare J, Berry RJ, Friedman JM, Erickson JD (2007). Race-ethnicity differences in folic acid intake in women of childbearing age in the United States after folic acid fortification: findings from the National Health and Nutrition Examination Survey, 2001-2002. American Journal of Clinical Nutrition;85(5):1409-16.

Wise A (1999). Appropriate uses for spreadsheets, databases and statistical software for the analysis of dietary data. International Journal of Food Sciences $\mathcal{E}$ Nutrition;50(2):111-5. 


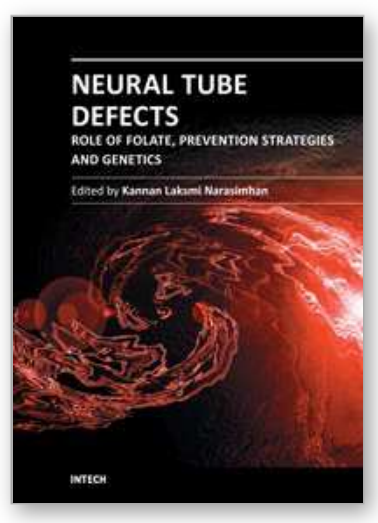

\section{Neural Tube Defects - Role of Folate, Prevention Strategies and Genetics}

Edited by Dr. Kannan Laksmi Narasimhan

ISBN 978-953-51-0317-2

Hard cover, 200 pages

Publisher InTech

Published online 16, March, 2012

Published in print edition March, 2012

The book Neural Tube Defects - Role of Folate, Prevention Strategies and Genetics has several eminent international authors and the book is a resource for anybody who is interested in this very important subject. The authors are distinguished and the chapters are a product of their extensive research.

\section{How to reference}

In order to correctly reference this scholarly work, feel free to copy and paste the following:

John A. A. Nichols (2012). Selective Abortion and Folic Acid Fortification as Contrasting Strategies for Prevention of Congenital Neural Tube Defect, Neural Tube Defects - Role of Folate, Prevention Strategies and Genetics, Dr. Kannan Laksmi Narasimhan (Ed.), ISBN: 978-953-51-0317-2, InTech, Available from: http://www.intechopen.com/books/neural-tube-defects-role-of-folate-prevention-strategies-andgenetics/selective-abortion-and-folic-acid-fortification-as-contrasting-strategies-for-prevention-of-congenit

\section{INTECH}

open science | open minds

\author{
InTech Europe \\ University Campus STeP Ri \\ Slavka Krautzeka 83/A \\ 51000 Rijeka, Croatia \\ Phone: +385 (51) 770447 \\ Fax: +385 (51) 686166 \\ www.intechopen.com
}

\author{
InTech China \\ Unit 405, Office Block, Hotel Equatorial Shanghai \\ No.65, Yan An Road (West), Shanghai, 200040, China \\ 中国上海市延安西路65号上海国际贵都大饭店办公楼 405 单元 \\ Phone: +86-21-62489820 \\ Fax: $+86-21-62489821$
}


(C) 2012 The Author(s). Licensee IntechOpen. This is an open access article distributed under the terms of the Creative Commons Attribution 3.0 License, which permits unrestricted use, distribution, and reproduction in any medium, provided the original work is properly cited. 